\title{
Pötr Simon Pallas'ın Tüm Dillerin ve Lehçelerin Karşılaştırmalı Sözlüğü Üzerine Leksikografik İnceleme*
}

\section{Lexicographical Review of Peter Simon Pallas's "Comparative Dictionaries of All Languages and Dialects"}

\author{
Alina MINSAFINA**
}

*Bu makale 3-4 Kasım 2015 tarihinde yapılan II. Uluslararası Sözlükbilim Sempozyumunda sözlü bildiri olarak sunulmuştur.

\section{ORCID: A.M. 0000-0001-6413-8429}

"Sorumlu yazar/Corresponding author: Alina Minsafina (Dr.),

İstanbul Üniversitesi, Edebiyat Fakültesi,

İstanbul, Türkiye

E-posta: minsafina@yandex.com

Başvuru/Submitted: 15.06 .2020

Kabul/Accepted: 05.07.2020

Atıf/Citation: Minsafina, A. (2020). Pötr Simon Pallas'ın Tüm Dillerin ve Lehçelerin Karşılaştırmalı Sözlüğü Üzerine Leksikografik Inceleme. Dilbilim Dergisi - Journal of Linguistics, 35, 1-13. https://doi.org/10.26650/jol.2020.006

\section{öz}

Zengin bir sözlük geleneğine sahip olan Rus sözlükbilimi, gelişme tarihi içinde önemli sözlükler ortaya koymuştur. Bu sözlüklerden bir tanesi, XVIII. yüzyılda II. Ekaterina emriyle hazırlanmış Tüm Dillerin ve Lehçelerin Karşılaştırmalı Sözlüğü Rus sözlükbilimde kavram sözlük türünün ilk örneklerindendir. Daha grandüşesken karşılaştırmalı dilbilimine merak salan imparatoriçe, dünyanın tüm dillerinin ortak bir kaynaktan gelmesi fikriyle evrensel sözlüğün hazırlanması için çalışmalar yürütmüştür. II. Ekaterina tarafından hazırlanan kelime listesi bu sözlüğün temelini oluşturmuştur. İmparatoriçenin topladığı bu malzeme daha sonraki çalışmalar için Alman kökenli bilim adamı Pötr Simon Pallas'a verilmiştir. 1787 ve 1789 yıllarında Tüm Dillerin ve Lehçelerin Karşılaştırmalı Sözlüğü iki cilt olarak yayınlanmıştır. (Rus dilbilimde bu sözlük aynı zamanda II. Ekaterina sözlüğü veya Pallas sözlüğü olarak da adlandırılmaktadır). Bu kavram sözlüğünde 285 Rusça sözcük 200 dil ve lehçeye çevrilmiştir. Sözlüğün dikkate değer iki özelliği vardır. Bunlardan bir tanesi, sözlüğün kavram sözlük özelliklerine sahip olması; diğeri ise sözlükte verilen dil ve lehçe düzenidir.

Anahtar kelimeler: Kavram sözlüğü, Rus sözlükbilimi, Ekaterina sözlüğü, Pallas sözlüğü

\section{ABSTRACT}

Russian lexicography has a rich dictionary tradition and has produced important dictionaries throughout its history of development. One of these dictionaries is The Comparative Dictionary of All Languages and Dialects prepared in the $18^{\text {th }}$ century by order of the Empress Ekaterina. Ekaterina was fascinated by comparative linguistics and thus decided to create a universal dictionary. The list of 300 words prepared by the empress herself formed the basis of this work. Later the work on the dictionary was continued by German scientist Peter Simon Pallas resulting in two volumes of Comparative Dictionary of All Languages and Dialects being published in 1787 and 1789. (In Russian linguistics this dictionary is also known as Ekaterina's dictionary or Pallas dictionary). This conceptual dictionary contains 285 Russian words with their translations into 200 languages and dialects. The structure of the dictionary and the languages and dialects arrangement in it are two most remarkable features of this lexicographical opus. Keywords: Conceptual dictionary, Russian lexicography, Ekaterina's dictionary, Pallas dictionary 


\section{Giriş}

Sözlük, bir dilin veya bir dilin bir bölümünün genel olarak veya belirli bir zamanda kullanılan dil birimlerinin genellikle alfabe sırasında, bazen de kavram alanlarına göre ele alıp aynı dilde tanımlarını veren veya başka bir dildeki karşılıklarını yazan, örnek vererek açıklayan bir kitaptır (Topaloğlu, 2010, s. 25).

Köklü bir geçmişe sahip olan Rus sözlükbilimi 1282 yılında yapılan Novgorodskaya Kormçaya ile başlayarak günümüze kadar önemli sözlükler ortaya koymuştur. Değişik sözlük çeşitleri arasında çeviri sözlükleri önemli bir rol oynamaktadır ${ }^{1}$.

Rusya'da diğer dillere merak ve karşılaştırmalı dilbilimin tarihi XVIII. yüzyılda Mihail Lomonosov (1711-1765) ile başlamıştır. Rusça ve Rusçanın değişik lehçelerine, Eski Rusça ve Eski Slavcaya hâkim olan Lomonosov, Rusça, Lehçe, Bulgarca, Sirpça, Çekçe, Slovakça gibi dillerin Slavcadan geldiğini belirtmiştir. Şüphesiz Lomonosov'dan önce de karşılaştırmalı dil çalışmaları yapılmıştır, yalnız Lomonosov bu karşılaştırmaları daha düzenli ve sistemli hale getirmiştir (Makayev ve Gadjiyeva, 1974, s. 34).

Lomonosov, çalışmalarında akraba dillerin aynı kaynaktan (anadilden) gelmeleri ve onların daha sonra çeşitli dallara ayrılıp çağdaş Hint-Avrupa dillerinin oluştuğu tezini ortaya koymuştur. Slav ve Hint-Avrupa dillerinin yanı sıra Türk, Fin-Ugor ve Kafkasya dilleri üzerine de çalışılmıştır.

Dillerin karşılaştırmalı olarak öğrenilmesi XVIII. yüzyıl Rus dilbiliminin karakteristik özelliğidir. Bu karşılaştırmalı çalışmalar yüzyılın sonunda Tüm Dillerin ve Lehçelerin Karşılaştırmalı Sözlüğ̈̈ [Сравнительный словарь всех языков и наречий] ile sonuçlandırılmıştır. Benzeri olmayan bu yapıt Pötr Simon Pallas (1741-1811) tarafından imparatoriçe Ekaterina'nın emriyle hazırlanmıştır. Bundan dolayı da Rus dilbiliminde bu sözlük aynı zamanda II. Ekaterina sözlüğ̈̈ veya Pallas sözlüğü olarak da adlandırılmaktadır.

Ekaterina daha grandüşesken (1745-1762) karşılaştırmalı dilbilime karşı ilgi duymaya başlamıştır, yalnız evrensel sözlük üzerine çalışmalar ancak 1784 yılında başlamıştır. Buliç’e göre (1904, s. 224-225) o zamanlarda Ekaterina Fransalı Antoine Court de Gébelin etkisi altında kalmıştır. Illkel Dünya Analizi ve Onun Modern Dünya ile Karşılaştırılması [Monde Primitif Analysé et Comparé Avec le Monde Moderne] çalışmasında Court de Gébelin, tüm dillerin tek bir temel dilden türediğini ortaya koymuştur. Bundan sonra ise Ekaterina kendi çalışmalarına başlamış ve 9 aydır gelecek sözlük için malzeme toplamıştır. 1785 yılında bir mektupta yazdıklarına göre Ekaterina üç yüze yakın sözcükten oluşan liste hazırlamış ve bu sözcükleri mümkün olduğu kadar çok dile ve lehçeye çevrilmesi için emretmiştir. Bir süre sonra bu çalışmalardan sıkılmaya başlayan Ekaterina, toplamış olduğu bütün verileri Pötr Simon Pallas'ın ellerine teslim etmiştir. Pallas dışında Ekaterina'nın yardımcıları arasında gelecek imparatoriçe için dünya dilleri üzerine yorum hazırlayan Berlinli bilim adamı ve kitap satıcısı Fridrih Nikolai da vardı.

1 Daha detaylı bilgi için bkz.: Minsafina Rus Sözlükçülüğü ve Tarihi ve Çağdaş Türk Lehçelerinde Rusça-Türkçe Sözlükler, yüksek lisans tezi, 2015 


\subsection{Sözlü̈̆̈̈̈n Ortaya Çıkması}

Sözlügün önsözünde Pallas, sözlükte bulunan Rusya topraklarında yerleşen dillerin kaynakları olarak el yazma sözlüklerin kullanıldığını söylemiştir. Pallas tarafından sözcük ve dil malzemesi toplama programı hazırlanmıştır. 1785 yılında başkentten bölgelere Ekaterina tarafından seçilmiş Rusça sözcükler için yerli dil ve lehçelerde karşılıklar bulunacağ emri gönderilmiştir. Bölgelerdeki resmî tercümanlar verilmiş sözcüklerin karşılıklarını bularak bu listeleri vilayet kalem odası memurların imzalarıyla başkente geri göndermişlerdir. Sözcük toplama programı Çin, Brezilya, Kuzey Amerika gibi ülkelere de yürütülmüştür. Yabancı bilim adamları kendi kitaplarını, malzemelerini, tavsiyelerini yollayarak bu çağrıya karşılık vermişlerdir (Buliç, 1904, s. 226).

Bunun dışında sözlük hazırlayıcıları bazı sözlük çalışmalarından daha önce yapılmış el yazma sözlüklerden de faydalanmışlardır. Böylece, II. Ekaterina himayesi altında hazırlanmış ama bugüne kadar korunmamış Daniil Dümareck'in Doğu Dillerin Karşılaştırmalı Sözlüğü [Comparative Vocabulary of Eastern Languages]'nün de kaynaklar arasında bulunması düşüncesi vardır (Cross, 1997, s. 99).

Evrensel sözlüğün kaynakları arasında Login İvanoviç Bakmeyster'in arşivi de kullanılmıştır. Buliç'in (1904, s. 222-223) verilerine göre Bakmeyster, daha sonra bilim adamlarının (Pallas dahil) kullandıkları tüm dillerinin sözlüğü için çok malzeme toplamıştır. 1773 yılında Bakmeyster dünya bilim adamlarına bildikleri dillerinin örneklerini göndermesi ricasında bulunmuştur. Seyahatlere giden Rus akademi üyeleri için de Bakmeyster tarafından dil malzemesi toplama üzerine detaylı program hazırlanmıştı. Böylece Bakmeyster eline değişik dillerde metin örnekleri (İncil'den bir parça), metin sözlükleri ve dil üzerine yorumlar geçmiştir.

\subsection{Sözlüğ̈̈n Yapısı}

1787 ve 1789 yıllarında yayınlanan Tüm Dillerin ve Lehçelerin Karşılaştırmalı Sözlüğ̈̈ Editörden ӧпsӧz [Предисловие от издателя] ile başlamaktadır. Önsöz önce Rusça, sonra da Latince olarak verilmiştir. Ondan sonra Latince Indeks [Indicluls] yer almaktadır. İndekste bazı Batı Avrupa dilleri için kaynak olarak kullanılmış 10 tane (çoğunlukla sözlükler) kitap adı verilmiştir. Bundan sonra Rus alfabesinin harf açıklamaları [Explicito litterarum Alphabeti Rossici] kısmı bulunmaktadır (Savelyev, 2014, s. 20-21).

İlk ciltte 130 madde başı, ikinci ciltte ise 142 madde başı ve cildin sonunda 12 rakamın $(1-10,100,1000)$ çevirisi verilmiştir. Bunun dışında ikinci cildin sonunda iki ciltte de var olan madde başları Rusça ve Latince karşılıklarıyla sıralanmış, bulundukları sayfalar gösterilmiştir: 


\section{Р О С I И С b}

\section{словачъ, въ двухъ часпиях перьваго ошдъленйя, находящимся.}

\section{Въ І в́ой части.}

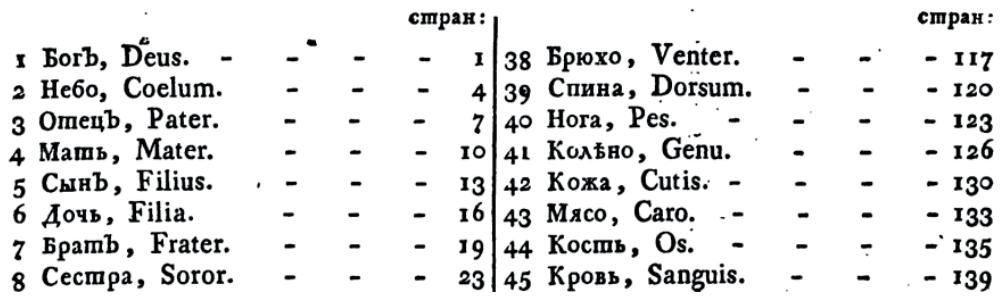

Şekil 1. Sözlükteki madde başları (Rusça, Latince)

Art arda gelen sözlük maddelerini belli başlıklar altında toplamak mümkündür. Böylece sözlükte aşağıdaki maddeleri ve madde gruplarını görmekteyiz:

\begin{tabular}{|c|c|c|}
\hline Sayfalar & Kategori & (Madde numarası) madde başıkıları \\
\hline \multicolumn{3}{|l|}{ I. Cilt } \\
\hline $1-4$ & İnanç & (1) Allah; \\
\hline 4-7 & Doğa & (2) Gök; \\
\hline $7-49$ & $\begin{array}{l}\text { Akrabalık } \\
\text { terimleri }\end{array}$ & $\begin{array}{l}\text { (3) Baba, (4) Anne, (5) Oğul, (6) Kız, (7) Kardeş, (8) Kız kardeş, (9) } \\
\text { Koca, (10) Karı, (11) Kız (evlenmemiş dişi insan), (12) Oğlan, (13) } \\
\text { Çocuk, (14) İnsan, (15) İnsanlar; }\end{array}$ \\
\hline $49-167$ & $\begin{array}{l}\text { İnsan organ ve } \\
\text { bölge adları }\end{array}$ & $\begin{array}{l}\text { (16) Baş, (17) Yüz, (18) Burun, } \\
\text { (19) Burun delikleri, (20) Göz, } \\
\text { (21) Kaşlar, (22) Kirpikler, (23) Kulak, (24) Alın, (25) Saç, (26) } \\
\text { Yanaklar, (27) Ağı, (28) Boğaz, (29) Diş, (30) Dil, (31) Sakal, } \\
\text { (32) Boyun, (33) Omuz, (34) Dirsek, (35) Kol, (36) Parmaklar, (37) } \\
\text { Tirnaklar, (38) Karı,, (39) Arka/Sırt, (40) Ayak, (41) Diz, (42) Cilt, } \\
\text { (43) Cisim, (44) Kemik, (45) Kan, (46) Kalp, (47) Süt, (48) İșitim, } \\
\text { (49) Görme, (50) Tadım, (51) Kuklam, (52) Dokunum, (53) Ses, (54) } \\
\text { Ad; }\end{array}$ \\
\hline 170-234 & $\begin{array}{l}\text { Bazı soyut } \\
\text { kavramlar }\end{array}$ & $\begin{array}{l}\text { (55) Çı̆̆glık, (56) Gürültü, (57) Feryat, (58) Söz, (59) Uyku, (60) } \\
\text { Sevgi, (61) Ağrı, (62) Emek, (63) İş, (64) Güç, (65) Kuvvet, (66) } \\
\text { İktidar, (67) Evlilik, (68) Yaşam, (69) Büyüme, (70) Ruh, (71) Ölüm, } \\
\text { (72) Soğuk, (73) Daire (Bir çemberle iç bölgesinin birleşimi), (74) } \\
\text { Küre; }\end{array}$ \\
\hline
\end{tabular}




\begin{tabular}{|c|c|c|}
\hline $234-411$ & $\begin{array}{l}\text { Doğa, mevsimler, } \\
\text { zaman }\end{array}$ & $\begin{array}{l}\text { (75) Güneş, (76) Ay, (77) Yıldız, } \\
\text { (78) Işın, (79) Rüzgâr, (80) Kasırga, (81) Fırtına, (82) Yağmur, (83) } \\
\text { Dolu, (84) Şimşek, (85) Kar, (86) Buz, (87) Gün, (88) Gece, (89) } \\
\text { Sabah, (90) Akşam, (91) Yaz, (92) İlkbahar, (93) Sonbahar, (94) Kış, } \\
\text { (95) Yıl, (96) Zaman, (97) Toprak, (98) Su, (99) Deniz, (100) Nehir, } \\
\text { (101) Dalgalar, (102) Kum, (103) Balçı, (104) Toz, (105) Çamur, } \\
\text { (106) Dağ, (107) Sahil, (108) Tepe, (109) Vadi, (110) Hava (Hava } \\
\text { yuvarını oluşturan, bütün canlıların solunumuna yarayan, renksiz, } \\
\text { kokusuz, akışkan gaz karışımı), } \\
\text { (111) Buhar, (112) Ateş, (113) Sıcak, (114) Derinlik, (115) Yükseklik, } \\
\text { (116) Genişlik, (117) Uzunluk, (118) Delik, (119) Çukur, (120) } \\
\text { Hendek, (121) Taş, (122) Altın, (123) Gümüş, (124) Tuz, (125) } \\
\text { Harika, (126) Orman, (127) Ot, (128) Ağaç, (129) Kazı,, (130) } \\
\text { Yeşillik. }\end{array}$ \\
\hline \multicolumn{3}{|l|}{ II. Cilt } \\
\hline $1-41$ & $\begin{array}{l}\text { Bitkilerle ilgili } \\
\text { sözcükler, meyve } \\
\text { adları }\end{array}$ & $\begin{array}{l}\text { (131) Meşe, (132) Kütük, } \\
\text { (133) Yapraklar, (134) Meyveler, } \\
\text { (135) Kabuk, (136) Kök, (137) Dal, (138) Kır, (139) Çayır, (140) } \\
\text { Buğday, (141) Çavdar, (142) Yulaf, (143) Üzüm; }\end{array}$ \\
\hline 41-107 & $\begin{array}{l}\text { Hayvanlarla ilgili } \\
\text { sözcükler }\end{array}$ & $\begin{array}{l}\text { (144) Balık, (145) Solucan, (146) Sinek, (147) Hayvan, (148) Öküz, } \\
\text { (149) İnek, (150) Koç, (151) Boynuz, (152) At, (153) Domuz, (154) } \\
\text { Köpek, (155) Kedi, (156) Sıçan, (157) Kuş, (158) Tüy, (159) Horoz, } \\
\text { (160) Yumurta, (161) Tavuk, (162) Kaz, (163) Ördek, (164) Güvercin; }\end{array}$ \\
\hline $107-150$ & $\begin{array}{l}\text { İş araçları ve } \\
\text { kullandıkları } \\
\text { yerler }\end{array}$ & $\begin{array}{l}\text { (165) Karasaban, (166) Tirmık, } \\
\text { (167) Sınır, (168) Ev, (169) Kapı, } \\
\text { (170) Avlu, (171) Şehir, (172) Ocak, (173) Ölçü, (174) Fıçı, (175) } \\
\text { Balta, } \\
\text { (176) Kemer, (177) Çivi, (178) Araba; }\end{array}$ \\
\hline $150-160$ & Yemekler & $\begin{array}{l}\text { (179) Ekmek, (180) Şarap, } \\
\text { (181) Yemekler; }\end{array}$ \\
\hline $160-170$ & - & (182) Hırsız, (183) Pusat, (184) Bekçi \\
\hline 170-224 & $\begin{array}{l}\text { Bazı soyut ve } \\
\text { somut kavramlar }\end{array}$ & $\begin{array}{l}\text { (185) Küfür, (186) Dövüş, (187) Bela, (188) Zafer, (189) Savaş, } \\
\text { (190) Savaşçı, (191) Tembellik, (192) Düzenlik, (193) Doğum, (194) } \\
\text { Döşeme, (195) Sürülmüş tarla, (196) Yük, (197) Gemi, (198) Balina, } \\
\text { (199) Aydınlı, (200) Gök gürültüsü; }\end{array}$ \\
\hline 224-312 & $\begin{array}{l}\text { Yaygın sıfatlar ve } \\
\text { zarflar }\end{array}$ & $\begin{array}{l}\text { (201) Genç, (202) Yaşlı, (203) Sağlıklı, (204) Yüksek, (205) Alçak, } \\
\text { (206) Büyük, (207) Az, (208) Beyaz, (209) Siyah, (210) Kırmızı, } \\
\text { (211) Yeşil, (212) Keskin, (213) Nemli, (214) Hafif, (215) Kalın, } \\
\text { (216) İyi, (217) İyi, (218) Güzel, (219) Hayırlı, (220) Kötü, (221) } \\
\text { Fena, (222) Fena, (223) Hızlı, (224) Yavaş, (225) Canlı, } \\
\text { (226) Memnun; }\end{array}$ \\
\hline $312-380$ & Yaygın fiiller & $\begin{array}{l}\text { (227) Yemek, (228) İçmek, (229) Şarkı söylemek, (230) Vurmak, } \\
\text { (231) Uyumak, (232) Yatmak, } \\
\text { (233) Almak, (234) Sevmek, } \\
\text { (235) Giymek, (236) Taşımak, } \\
\text { (237) Kesmek, (238) Ekmek, } \\
\text { (239) Toprak sürmek, (240) Saklamak, (241) Dökmek, (242) } \\
\text { Pişirmek, (243) Var, (244) Ver, (245) Dur, (246) Yürü; }\end{array}$ \\
\hline
\end{tabular}




\begin{tabular}{|c|c|c|}
\hline $380-468$ & $\begin{array}{l}\text { Yaygin zamirler, } \\
\text { edatlar, zarflar }\end{array}$ & $\begin{array}{l}\text { (247) Ben, (248) Sen, (249) O (eril), (250) O (dişil), (251) Biz, (252) } \\
\text { Siz, (253) Onlar, (254) Onlara, (255) Ne, (256) Neyle, (257) Kimle, } \\
\text { (258) Evet, (259) Hayır, (260) Nerede, (261) Burada, (262) Orada, } \\
\text { (263) Altında, } \\
\text { (264) Üstünde, (265) İçinde, (266) Ne zaman, (267) Şimdi, (268) } \\
\text { Önce, } \\
\text { (269) Sonra, (270) Gibi, (271) -sı,, } \\
\text { (272) Veya, (273) İşte; }\end{array}$ \\
\hline $468-491$ & Sayılar & $\begin{array}{l}\text { (274) Bir, (275) İki, (276) Üç, (277) Dört, (278) Beş, (279) Altı, (280) } \\
\text { Yedi, (281) Sekiz, (282) Dokuz, (283) On, (284) Yüz, (285) Bin. }\end{array}$ \\
\hline
\end{tabular}

Sözlükler, amaç, yöntem, malzeme, sunuş, hedef kitle bakımından farklı türlere ayrılmaktadır. Sözlük kullanıcılarının seçim ve tercihlerinde kolaylık sağlama yöntemleri çerçevesinde sözlük sınıflandırmasında da bazı ölçütler ortaya konulmuştur. Sözlük türleri ve bunların sınıflandırılması konusunda özellikle Batıda ve Rusya'da bugüne kadar pek çok çalışma yapılmıştır.

Rus sözlükbiliminde sözlük sınıflandırmasına yapılan ilk çalışmada dilbilimci Lev Sçerba altı tane karşıtlık belirleyerek sözlükleri onlara göre sınıflandırmıştır. Bu sınıflandırmada geleneksel sözlük türü kavram sözlük türüne karşıt olarak gösterilmiştir. Kavram veya ideolojik olarak adlandırılan sözlük türü geleneksel sözlüklerde yer alan alfabetik düzen yerine kavram düzenini esas alır. Kavram sözlüklerinin malzeme sunuş yöntemi, bu sözlükleri diğer tür sözlüklerden ayıran temel özelliktir. (Şçerba, 1974, s. 290).

Kocapınar'ın (2010, s. 311) belirttiği gibi, kavram sözlükleri için «tematik sözlükler», «konularına göre sözlükler», «adbilimsel sözlükler», «ideolojik (ideografik) sözlükler» terimlerin kullanıldığı görülmektedir. Bu terimler geleneksel alfabetik sözlüklerden farklı sözlük düzenleme yöntemini yansımaktadır: Kavram sözlüklerinde madde başları konulara göre yer almaktadır.

Kavram sözlükleri, insanların dünya görüşleri ile ilgili bilgilerinin gelişmesi açısından önemlidir. Aynı dilin tematik olarak düzenlemiş ama farklı dönemlerine ait söz varlığını bir araya getirince insan bilişinin gelişme hareketini nesnel olarak görmek mümkündür. Bir konunun büyüdügüünu ve başka bir konunun darlaştığını, bakış açısının değiştiğini, sözcüklerin gelişimi gibi özellikleri de kavram sözlüklerinden bulunabilir. Bu bakımdan dönemin aynası olan kavram sözlükleri insanın o döneme ait bilgileri aktarmaktadır (Morkovkin, 1970).

Tüm Dillerin ve Lehçelerin Karşılaştırmalı Sözlüğü'nün yapısına bakarak bunun bir kavram sözlüğü olduğu bellidir. Sözlükte bulunan madde başları temel kavramları karşılamaktadır, böylece sözlük yapısı ve madde başı sıralanması, insanların dünyaya bakışını ve hiyerarşik ilişkileri yansımaktadır. Kavram sözlüğünde dilin söz varlığı belli bir yapıda verilmektedir, Pallas sözlüğünde de madde başlarını semantik başlıklar altında toplamak mümkündür. Aynı gruptaki madde başları sıralanması da birkaç ilkeyi takip etmektedir: Eş anlamlı sözcükler veya anlamları yakın olan sözcükler (Küfür, Dövüş, Bela); karşıt anlamlı sözcükler (Savaş Zafer, Genç - Yaşlı, Beyaz - Siyah), çağrışımlı sözcükler (Daire (Bir çemberle iç bölgesinin 
birleşimi), Küre, Güneş), eş sesli sözcükler (Yemek [есть] - Var [есть], İçmek [пить] - Şarklı söylemek [петь]). Hem madde başları sıralanmasında hem de grupların sıralanmasında o zamanda yaşayan insanların dünyaya bakışını yansıtan hiyerarşiyi görmek mümkündür: İlk gelen sözcük Allah/Tanrı, sonra Gök, Akrabalık terimleri (yakın akrabalık terimleri - önce eril, sonra dişil), Bitki adları (insan hayatı için önemli buğdaygiller başta olmak üzere), Hayvanlar (önce böcekler, sonra evcil hayvanlar) vs. Böylece Tüm Dillerin ve Lehçelerin Karşılaştırmalı Sözlüğü kavram sözlüklerinin ilk örneklerinden biri olduğunu söylemek mümkündür.

Pallas Sözlüğü çok dilli bir sözlük olduğu için madde başı yapılandırmasında da bazı özellikler vardır. Aynı sözcüğün değiş̧ik dil ve lehçelerdeki karşılıklarını vermek için aşağıdaki düzen takip edilmiştir: Sayfanın başında Rusça madde başı yazılmıştır, sonra bu sözcügün değişik dillere çevirisi verilmiştir. Toplam olarak dil ve lehçe sayısı iki yüzdür. Her dil ve lehçeye sıra numarası gösterilmiştir ve her sözlük maddesinde dil veya lehçe aynı numara altında verilmiştir. Akraba dillerin (Slav, Germen, Türk) genel olarak art arda gelmeleri dikkate değerdir. Böylece, Pallas sözlüğünde erken ve oldukça başarılı dil sınıflandırılması yapılmıştır. Geleneksel olarak bu başarı Pallas'a ait olduğu söylenmektedir, ama aynı zamanda dil ve lehçe sıralanmasının Ekaterina kendisinin düzenlediği düşüncesini de dikkate almak gerekir (Ruhlen, 1987, s. 32).

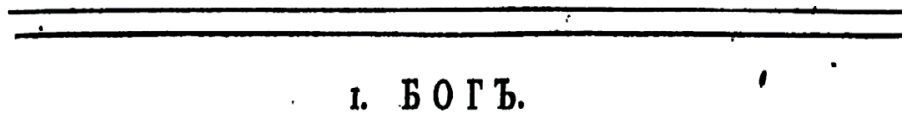

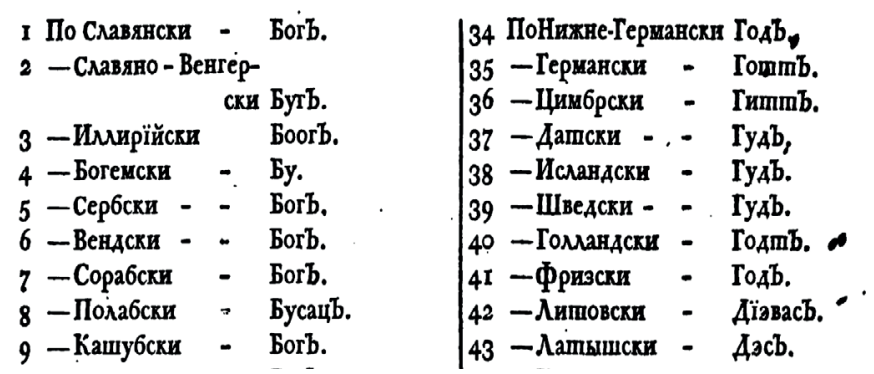

Şekil 2. Sözlükteki madde başı sözcüğün yabancı dil ve lehçelere çevirisi (Tanrı maddesi örneğinde)

Her Rusça madde başı için bir veya birden fazla karşılık verilmiştir. Karşılık bulunmadığı durumlarda dil veya lehçe yanında noktalar konulmuştur. Pallas'ın sözlüğün önsözünde yazdığı gibi, bu boşluklar daha sonra bu Sözlüğün gelecek sahipleri, yabancılar ve dil sevenler tarafından doldurulabilecektir (Pallas, 1787, önsöz).

Pallas sözlüğünün iki cildi çıktıktan sonra II. Ekaterina bu sözlüğün yenilenmiş ve tamamlanmış versiyonunu çıkartmaya emretmiştir. Bu defa sözlükteki madde başları alfabetik olarak sıralanmıştır ve dil sayısı 279 olmuştur. Sözlük çalışmaları yöneten Födor Yankoviç (de Miriyevo) 1790-1791 yıllarında 4 ciltli Alfabetik Olarak Sıralanmış Tüm Dillerin ve 
Lehçelerin Sözlüğ̈̈ [Сравнительный словарь всех языков и наречий, по азбучному порядку расположенный]'nü yayınlamıştır (Savelyev, 2014, s. 21-22).

Sözlügün yeni baskısında madde başı düzeni dillerin akrabalık ilişkilerini göstermede başaramamıştır. Birbirlerini takip eden madde başları genellikle farklı dillerden olup değişik anlamlar karşılamışlardır:

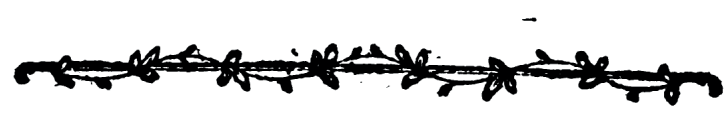

\section{C a.}

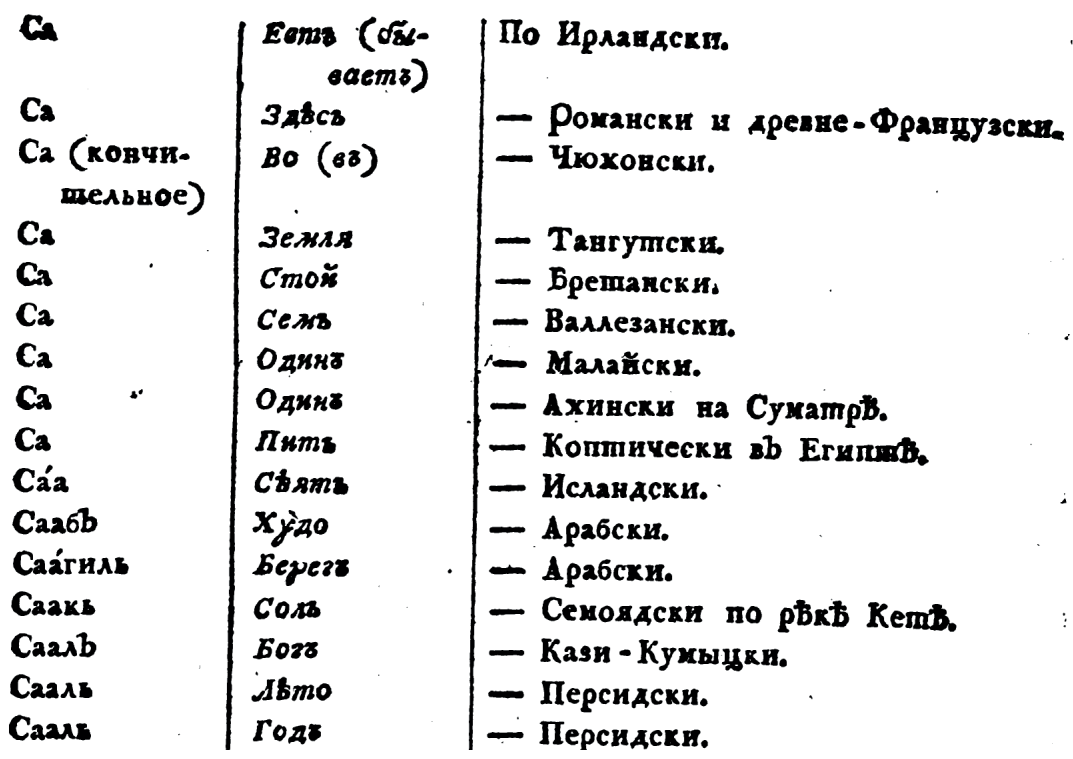

Şekil 3. Sözlüğün yeni baskısında maddelerin alfabe sırasına göre yerleşmesi

(S harfi örneğinde)

\subsection{Sözlükteki Dil ve Lehçeler Üzerine}

Pallas sözlüğünde 200 dil ve lehçe yer almıştır. Böyle bir sözlüğün Rusya'da meydana gelmesi Pallas’a göre şaşırtıcı değildir. Sözlüğün önsözünde, tarihte bilinen devletlerin hiçbirisi hem büyüklüğüyle hem de içinde yaşayan millet sayısı ve konuşulan dil farklılığıyla Rusya İmparatorluğu ile kıyaslanamaz. Daha detaylı mukayese sonucunda Roma İmparatorluğu bile kaybeder, demiştir. Bu yüzden de Pallas'a göre hiçbir devletten de Tüm Dillerin ve Lehçelerin Karşılaştırmalı Sözlüğü’ne benzer bir çalışma beklemek mümkün değildir (Pallas, 1787, önsöz). 
Sözlükte yer alan bazı lehçelerin adları ilk defa kaydedildiğinden dolayı bu dil ve lehçeler üzerine sözlüğün önsözünde açıklamalar verilmiştir.

Sözlügün madde başları Rusçadır. İlk 12 dil ve lehçe Pallas'a göre Slav dilleri ailesindendir (bu 12 dil ve lehçe arasında 3-İlliriyçe, 4-Çekçe, 5-Sırpça, 10-Lehçe vb.).

Daha sonra (13-19) Kelt dilleri yer almıştır. Kelt dillerinden sonra 20-Eski Yunanca ve 21-Yeni Yunanca yerleşmiştir. 22 numara altında Latince ve daha sonra Latinceye yakın diller verilmiştir: 23-İtalyanca, 25-İspanyolca, 26-Portekizce, 27-Eski ve 28-Yeni Fransızca. 31-41 numaralar arasında Germen dilleri dahil edilmiştir. Bunların arasında 32-İngilizce, 35-Almanca, 37-Danimarka dili, 38-İzlanda dili, 40-Hollandaca (40) bulunmaktadır. 42-44 numaralar Baltık dilleridir. 45 - Arnavutça, 47 - Macarca. Sözlügüun önsözünde Pallas, bu numaraya kadar var olan dil ve lehçeler Bekmeyster tarafından toplanmış olduğunu belirtmiştir.

48-Avarcadan başlayarak ve sözlüğün sonuna kadar yer alan dil ve lehçeler Pallas'ın tarafından toplanmıştır. 49-53 numaralar arasında diğer Kuzeydoğu Kafkas dilleri yerleşmiştir. Daha sonra Fin-Ugor dilleri ve lehçeleri (55-75) konulmuştur.

Fin-Ugor dilleri arasında 63-Mari ve 65-Udmurt dilleri arasında 64 numara altında bugün Türk dilleri ailesine ait olan Çuvaşçanın yerleşmesi dikkat çekicidir. Bilindiği kadarıyla Pallas sözlüğü hazırlandığında Çuvaş dili üzerine daha önceki eserler dikkate alınmamıştır. Egorov (1949, s. 131), Pallas sözlüğün ikisi de arasında uyumlu olsa bile diğer XVIII. yüzyıl sözlükleriyle uyumlu olmadığını belirtmiştir. Egorova'a göre hazırlayıcılar yazılı sözlüklerden değil de daha çok yerli Çuvaşça bilenlerden faydalanmıştır. Sıkça bir Rusça sözcük için birkaç tane Çuvaşça karşılık verilmiştir. Bunu, Çuvaş dilinin malzemesi birkaç tane değişik kaynaklardan toplanmış olması ile açıklayabilmek mümkündür (Savelyev, 2014, s. 21).

Fin-Ugor dillerinden sonra 76-Farsça ve 77-Kürtçe yerleşmiştir. Daha sonra Sami dilleri yer almıştır. Bunların arasında 81-İbranice, 85-Arapça, 86-Maltaca gibi diller gösterilmiştir.

88-106 numaralar altında Türk dilleri sıralanmıştır. Türk dilleri arasında ilk gelen dil 88-Türkiye Türkçesidir. Sonra Tatarca ve Tatarcanın lehçeleri gösterilmiştir. Bugün ayrı diller olarak kabul ettiğimiz 91-Başkurtça, 92-Nogayca, 93-Kazakça Tatarcanın lehçeleri olarak verilmiştir. Bunun dışında 101-Altayca, 105-Kafkas Türkmencesi, 106-Yakutça gibi diller de vardır: 


\subsection{Sözlük ile İlgili Yapılan Değerlendirmeler}

II. Ekaterina sözlüğü bilim adamlarının dikkatini çekmiştir. Sözlük üzerine eleştiri yazılarını Bakmeyster, Kraus, Bütner, Rüdiger, Hager, Volney, Dobrovskiy, Alter, Fra Bartolomeo yazmışlardır. Eleştiricilerin çoğu, hazırlanmış sözlüğün kapsamı ve içeren malzemesine hayran kalmışlardır.

Buliç'e göre (1904, s. 228) bu yazıların arasında en sağlam ve yansız eleştiri Kraus'a aittir. İlk olarak Kraus sözcüklerin telaffuzunun yazıma aktarılması üzerine şüphelenmektedir. Bazı komşu dillerinin yazıya aktarılmasında hatalar bulmuş Kraus daha uzak veya yazılı olmayan diller için hatalarının yapılmaması imkânsız olduğunu dile getirmiştir. Kraus, bazı yabancılara ve özellikle pek büyük olmayan kabilelere $u z u n l u k$, kuvvet, sevgi gibi soyut kavramları anlatmak oldukça zor olduğundan dolayı sözlükteki bazı karşılıkların da yanlış olabileceğini belirtmiştir. Bunun dışında dilin veya lehçenin dilbilgisi dikkate alınmadan bazı karşılıkların verilmesinde hata oluşturabilmiştir. Kraus'a göre dilbilgisi incelemeleri bu sözlügün temel amacı olan diller arasındaki akrabalık ilişkileri daha net şekilde ortaya koyabilirdi. Bazı sıkıntılar dillerin yanlış adlandırılması veya bir dilin başka bir dil olarak kabul edilmesi ile ilgilidir. Ciddi bir eleştiri yaptığına rağmen Kraus bu sözlüğün büyük ve kapsamlı çalışma olduğunu işaretlemiştir.

Oldukça sert eleştiri Hager tarafından da yapılmıştır. Hager'a göre tüm Asya dillerinin karşılaştırmalı sözlüğün yapılması imkansızdır. Türkçe ve Tatarcada çok fazla Arapça ve Farsça alıntıların olması karışık bir duruma getirebileceğini belirten Hager, bu dildeki alıntı karşılıklarını hiç alınmaması gerektiğini dile getirmiştir. Arapça ile ilgili gözlemlerde ise Hager, Arapça karşılıklarda hem eski hem de yeni Arapça sözcükler kullanılmış ve Arapçanın çeşitli lehçelerine dikkat edilmemiş gibi sonuçlara varmıştır, İbranice, Ermenice, Japonca karşılıklarda da hataların var olduğunu tespit etmiştir. Bunun dışında bazı dil ve lehçeler sözlükte çarpıtılmış şekilde verilmiştir. Bu çarpıtmalar Tatarca ve Tatarcanın lehçelerinde, Farsça, Arapça, bazı Hint lehçelerinde, Çincede görülmektedir (Buliç, 1904, s. 230).

Buliç'e göre (1904, s. 231) bu eleştiriciler arasında herhangi bir Rusça ad bulunmaması ilgi çekicidir. Bunu Buliç sözlüğün yayılması ile açıklamak mümkün olduğunu ifade etmektedir. İmparatoriçe Ekaterina kendisi bu sözlüğü yabancı bilim adamlarına ve saraylara yollamıştır. Rusya'da ise satışa yalnız 40 sözlük nüshası çıkmıştır. Yanı Rus halkının sözlüğe ulaşması neredeyse imkansızdı. Yankoviç (de Miriyevo) sözlüğü de uzun zamandır satılmamıştır (1813 yılına kadar), İmparatoriçenin çalışma odasında saklı kalmıştır.

\section{Sonuç}

Sözlük bir referans kitabıdır. Sözlüklere tahminen insanların bulmak istedikleri sözcüklerle beraber insanların şu anda ilgilenmedikleri ama ulaşmak istedikleri madde ve bilgileri içerir. Böylece sözlük referans kitabından daha fazlası olup bir dilin söz varlığının kaydıdır (Jackson, 2016, s. 45). 
Çok fazla eksikliklere rağmen, eleştirilecek konu aslında sözlük yapma fikri değil de sadece sözlük yapma yöntemleridir. Evrensel sözlük hazırlanma amacı o zamanda mevcut olan tüm dillerinin aynı kaynaktan gelmesi fikrini ispatlamaktı. Sözlük üzerine yazılmış bir sürü eleştiri yazıları bile XVIII. yüzyıl ilmi için çok şey kazandırmıştır. Sözlüğün olumlu taraflarından biri ise yeni dil malzemenin zenginliği ve daha önce Avrupa'ya geçemeyen bazı Rusya, Sibirya ve Asya dil ve lehçeleri üzerine yeni verilerdir. Bunun dışında bazı dil ve lehçeler ilk defa bu sözlükte geçtiği için Pallas sözlüğ̈̈ birçok dil ve lehçenin ilk yazılı kaynağı olarak kabul edilmektedir. Rusya sınırları içinde pek etkileyici olmayan bu sözlük daha sonra Avrupa’ya Adelung'un Mitridat veya Evrensel Dilbilim [Mithridates oder allegemeine Sprachenkunde], Gervas'ın Diller [Katalogu Catalogo de las lenguas de las naziones] gibi eserleri kazandırmıştır.

Pallas'ın dil sezgisi dil ve lehçe karşılaştırması için uygun sözcükler seçmeye yardım etmiştir. Sözlükte yer alan madde başları dilin derin ve çok fazla değişikliklere uğramayan dil tabakasına aittir. Daha sonra, 1950 yıllarında glottokronoloji yöntemi için Swadesh tarafından seçilmiş sözcük listesinde, Pallas sözlüğünde dillerin akrabalık ilişkilerini tespit etmek için konulmuş sözcüklerin çoğu bulunmaktadır.

\footnotetext{
Hakem Değerlendirmesi: Dış bağımsız.

Çıkar Çatışması: Yazar çıkar çatışması bildirmemiştir.

Finansal Destek: Yazar bu çalışma için finansal destek almadığını beyan etmiştir.

Peer-review: Externally peer-reviewed.

Conflict of Interest: The author has no conflict of interest to declare.

Grant Support: The author declared that this study has received no financial support.
}

\section{Kaynakça/References}

Buliç, S. (1904). Oçerki istorii yazıkoznaniya v Rossii 13-19vv. Sankt-Peterburg: Tipografiya M. Merkuşeva.

Cross, A. G. (1997). By the banks of Neva: Chapters from the Lives and Careers of the British in EighteenthCentury Russia. Cambridge University Press.

Egorov, V. (1949). Çuvaşskiye slovari XVIII veka. Zapiski NïIYaLI pri Sovete ministrov Çuvaşskoy ASSR, Vlp. 2, 111-142.

Jackson, H. (2016). Sözlükbilime Giriş. (M. Gürlek, E. Patat, Çev.) İstanbul: Kesit.

Kocapınar, P. (2010). Sözlük Sınıflandırmalarında «Tematik Sözlük»ün yeri. Türkiye'de ve ve Dünay'da Sözlük Yazımı ve Araştırmaları Uluslararası Sempozyumu Bildirileri, 1, 302-313.

Makayev, E. ve Gadjiyeva, N. (1974). Sravnitelnoye yazıkoznaniye v istorii Akademii Nauk. Voprosı yazıkoznaniya, 5, 34-48.

Morkovkin, V. (1970). İdeografiçeskiye slovari. Moskva: İzdatelstvo Moskovskogo universiteta.

Pallas, P. (1787). Sravnitelniye slovari vseh yazkov i nareçiy, sobranniye desnitsey vsevisoçayşey osobl, otdeleniye pervoe, soderjaşçee v sebe evropeyskiye i aziatskiye yazıki. Çast pervaya. Sankt Peterburg: Tipografiya Şnora. 
Pallas, P. (1789). Sravnitelnıye slovari vseh yazkov i nareçiy, sobrannıye desnitsey vsevisoçayşey osobı, otdeleniye pervoe, soderjaşçee v sebe evropeyskiye i aziatskiye yazıki. Çast vtoraya. Sankt Peterburg: Tipografiya Şnora.

Ruhlen, M. (1987). A Guide to the World's Languages, Vol. 1: Classification. Stanford: Stanford University Press.

Savelyev, A. (2014). Ortajeniye dialektnıh osobennostey v staropismennıh pamyatnikah çuvaşskogo yazıka 18 veka (na materiale slovarya Pallasa). Dissertatciya na soiskaniye uçenoy stepeni kandidata filologiçeskih nauk. Moskva: İnstitut yazıkoznaniya RAN.

Şçerba, L. (1974). Opıt obşçey teorii leksikografii. Yazıkovaya sistema i reçevaya deyatelnost. Moskva: Nauka, 265-304.

Topaloğlu, A. (2010). Türkçede Genel ve Özel Sözlükler ve Sözlük Yazımı. Türkiye'de ve Dünya'da Sözlük Yazımı ve Araştırmaları Uluslararası Sempozyumu Bildirileri, 1, 25-27.

Voloşina, O. (2012). «Sravnitelıy slovar vseh yazıkov» Petra Simona Pallasa. Vestnik Nijegorodskogo universiteta im. N. I. Lobaçevskogo, 6 (1), 354-356.

Slovar vseh yazıkov i nareçiyi po azbuçnomy poryadku raspolojennıy. Çast pervaya A - D. (1790). SanktPeterburg.

Slovar vseh yazıkov i nareçiy po azbuçnomy poryadku raspolojennıy. Çast vtoraya D - L. (1791). Sankt-Peterburg. Slovar vseh yazıkov i nareçiy po azbuçnomy poryadku raspolojennıy. Çast tretya L - S. (1791). Sankt-Peterburg. Slovar vseh yazıkov i nareçiy po azbuçnomy poryadku raspolojennıy. Çast çetvertaya $S-\theta$. (1791). SanktPeterburg. 
